\title{
Recruitment and retention project team
}

\section{Opportunities and outcomes}

by Ninfa Trejo and Elaina Norlin

I $t$ has become a challenge for institutions of higher education to foster and retain cultural diversity among academic librarians. The University of Arizona (UA) is a teambased learning organization that strives to explore avenues for recruiting a diverse staff that will represent the ethnic demographics on campus.

In its efforts to continue its progress toward becoming a diverse and inclusive organization, the UA library has included within its strategic planning a project team called Recruitment and Retention ( $R \& R$ ). The project team was to look at ways to overcome cultural and geographic barriers by exploring the possibilities of encouraging minority librarians to pursue positions in an academic environment. This article describes the different stages of this program, from strategic planning to implementation.

\section{Strategic long-range planning team}

The UA team environment does not use library department heads to implement the strategic work of the library. Instead, the library assigns different project teams whose one- or two-year assignment is to help advance the library's strategic mission. The UA library has a special project team called Strategic Long-Range Planning (SLRP), whose re- sponsibilities include analyzing previous strategic goals and developing new directions for the upcoming year.

To develop the strategic goals for the following year, SLRP gathers information to place in what is called a Current/Future Situation Analysis (C/FSA) document. The C/FSA is the product of a review of the library's mission and vision statements, extensive input from the library, literature reviews, and the university's strategic direction. After the C/ FSA document is completed, SLRP develops the strategic long-range plan. This plan is then distributed to the library for a final review. The goals for 1999-2000 were education, infrastructure, access, and staff environment. ${ }^{3}$

\section{Action planning team}

During 1999-2000, the Action Planning Team (APT) was formed to study the Staff Environment goal to see if the library was having a problem with recruiting and hiring new employees and to review retention issues and mentoring for all library staff members. As in many academic libraries all over the country, attracting and retaining people of color has been a continuous, uphill battle. The UA library has made significant strides in recruiting people of color but was concerned about taking proactive measures for retaining not

\section{About the authors}

Ninfa Trejo is social sciences librarian and Elaina Norlin is undergraduate services librarian at the University of Arizona, email: trejon@u.library.arizona.eduand norline@u.library.arizona.edu 

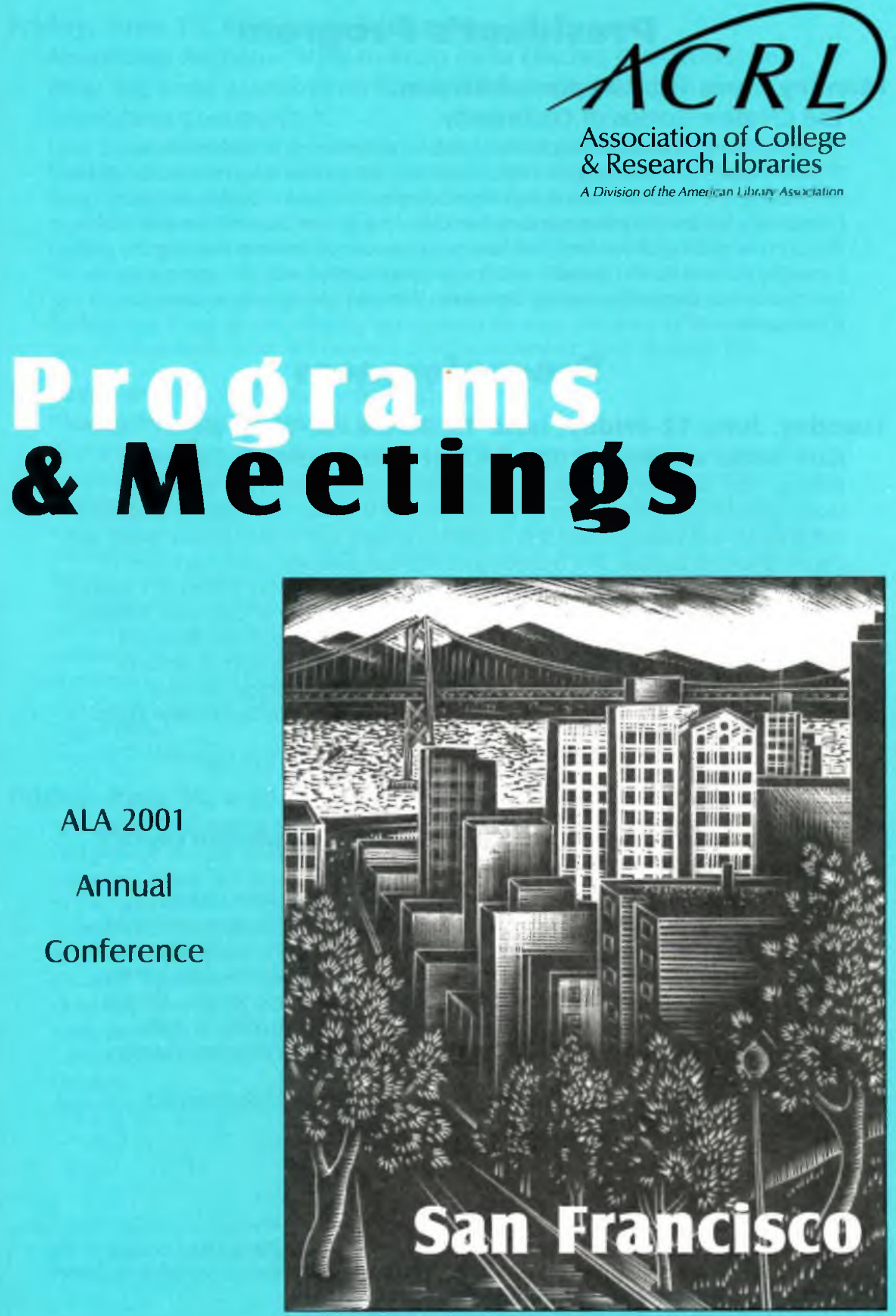


\section{President's Program}

\section{Monday, June 18, 2:00 p.m.-4:00 p.m.} The Creative Genius of Community

Sherman Alexie, award-winning author, poet, screenwriter, and Spokane/Coeur d'Alene Indian from Washington state, celebrates the collaborative relationship of the community, the historical record, and the storyteller. His books, poetry, and films consistently tell the story that needs to be told-that all communities are enriched through the sharing of our lives. The library, as a house of stories preserving the past, providing a home for the present, and forging partnerships with the community, is essential to our democratic society. Speaker: Sherman Alexie, author, poet, and screenwriter.

\section{Preconferences}

\section{Tuesday, June 12-Friday, June 15, 8:30 a.m.-12:30 p.m.} Rare Books and Manuscripts Section-"The Twentieth Century" Entitled "The Twentieth Century," the 42nd RBMS Preconference will explore the challenges and opportunities we face as builders of 20th-century research collections. The program will examine collecting practices, formats, and constituencies, along with the evolutionary, cultural, and technological changes that bear upon the nature of contemporary recorded information. Speakers: Samuel Brylawski, Library of Congress; Penny Pittman, The J. Paul Getty Trust; Paul Duguid, University of California, Berkeley; Stephen Ennis, Emory University; Peter Hirtle, Cornell University; Susan Kornfield, Bodman, Longley, and Dahling LLP; Henry Lowood, Stanford University; Annette Melville, National Film Preservation Foundation; Diane Middlebrook, Stanford University; Libbie Rifkin, Folger Shakespeare Library; and Marvin Taylor, New York University.

Fees: ACRL Members: $\$ 195$; Non Members: $\$ 230$; Late Fee (after May 11): $\$ 50$

\section{Friday, June 15, 8:30 a.m.-5:00 p.m.}

\section{"Reaching Students and Faculty: Putting the Information Literacy Competency Standards to Work"}

Learn strategies to implement the newly adopted ACRL Information Literacy

Competency Standards for Higher Education on your campus. Develop a thorough understanding of the standards and discover how to apply them to your instructional program. Speakers: Ann Fiegen and Gabriela Sonntag, ACRL information literacy consultants; Craig Gibson, associate university librarian for public services, George Mason University; JoAnn Carr, director, Center for Instructional Material and Computing, University of Wisconsin; Christie Flynn, reference/instruction librarian, Pierce College.

Fees: ACRL Members: $\$ 110$; ALA Members: $\$ 155$; Non Members: $\$ 200$; Students: $\$ 75$

Cover: The illustration is reproduced from a wood engraving by Mallette Dean housed in the Donohue Rare Book Room, University of San Francisco. The image shows Sacramento Street from atop Nob Hill looking toward the Bay Bridge. 


\section{Friday, June 15, 8:30 a.m.-5:00 p.m.}

Instruction Section-"How to Keep From Glazing Over When You Hear the Word Assessment: Realistic Strategies for the Library Instruction Community"

Gain the information and skills directly related to the assessment needs of instruction librarians. During this hands-on session, acquire tips from assessment specialists and return to your institution ready to apply your knowledge of assessment to your own program. Learn what questions to ask when designing assessment strategies, find out how to write assessment statements, and discover the types of tools needed for measuring learning outcomes. Speakers: Patricia Senn Breivik, dean, university library, San Jose State University; Debra Gilchrist, director of library media services, Pierce College; and Betsy Wilson, director of university libraries, University of Washington. Fees: ACRL Members: \$150; ALA Members: \$195; Non Members: $\$ 240$; Students: $\$ 95$

\section{Friday, June 15, 8:30 a.m.-5:00 p.m.}

\section{"Navigating the Licensing Landscape"}

With the rapid growth of databases, the number of licenses handled by libraries has grown exponentially. This change in scale means that it is even more important to have in place sound practices for tracking licenses, as well as policies and procedures that encourage or enforce compliance with the terms of the contract. During this one-day preconference, explore core issues to address in license negotiation, discuss selected problems and solutions in licensing language, examine current "hot" issues and recommended negotiation techniques, share negotiation strategies, and discover if the current licensing model is sustainable as libraries attempt to manage an ever-increasing number of licenses and contracts. Speakers: Ivy Anderson, coordinator for digital acquisitions, Harvard University Library; Kimberly Parker, electronic publishing and collections specialist, Yale University; and Beverlee French, executive director, California Digital Library.

Fees: ACRL Member $\$ 125$; ALA Member $\$ 165$; Non-Member: $\$ 205$; Student: $\$ 100$

\section{Friday, June 15, 8:30 a.m.-12:30 p.m.}

"Creating Successful Librarian-Faculty Collaborations: The State of the Art" First offered at ACRL's National Conference in Denver, this popular workshop has been expanded into a four-hour preconference. Gain the cutting-edge knowledge and tools to turn your institution into a nexus of librarian-faculty collaboration. Develop personal collaboration skills, assess the "Collaborative 1.Q." of your institution, learn about the best practices at other schools, and apply these practices to your own instructional situation. Speakers: Dane Ward, coordinator of library instruction, Central Michigan University; Dick Raspa, professor, Interdisciplinary Studies, Wayne State University; and other members of the team who created the best-selling ACRL publication "The Collaborative Imperative: Librarians and Faculty Working Together in the Information Universe."

Fees: ACRL Member $\$ 100$; ALA Member: $\$ 145$; Non-Member: $\$ 185$; Student: $\$ 75$ 


\title{
Programs
}

\section{Saturday, June 16}

\section{ACRL Community and Junior Colleges Library (CJCLS)}

\author{
9:00 a.m.-12:30 p.m., Track A: Leadership
}

\section{Assistive Technologies: The Real Issues Behind Access}

Every academic library faces the challenge and opportunity of redefining "access" to fully include patrons who are learning disabled, low-vision, blind, deaf and/or mobility impaired. How will your library develop and sustain a comprehensive "access framework" using assistive technologies? What do you need to know about new equipment and tools? What about legal responsibilities, staff training, and service issues? An expert panel discusses the California community colleges' efforts to address these issues. Speakers: Sarah Hawthorne, attorney, U.S. Office for Civil Rights; Carl Brown, director, High Tech Center Training Unit, California Community Colleges; Marcia Norris, trainer, High Tech Center Training Unit, California Community Colleges; Johanna Bowen, director, Cabrillo College Library; Tabzeera Dosu, director of library services, Butte College.

\section{SPARC/ACRL Forum, San Francisco}

11:00 a.m. $-12: 30$ p.m.

\section{Outward Bound: Effecting Change in Scholarly Communication from Outside the Library}

In this session, attendees will be exposed to speakers whose commitment to change in scholarly communications takes place outside of the library context, though in many cases awareness of the issue was sparked by the library. Speakers will relate their experience from a faculty, provost/administrative, and research perspective while communicating to attendees the most successful ways to reach out to those communities and build these constituencies. Finally, two speakers will demonstrate their experience creating a library-published journal and a library-based e-print archive, illustrating successful models of faculty-library collaboration in launching "e-nitiatives." Attendees will also receive an update on developments in SPARC's UK/European growth.

\section{ACRL African American Studies Section (AFAS)}

\section{2:00 p.m.-4:00 p.m., Track G: Issues \& Updates}

\section{African American Studies and Librarianship: A Natural Relationship}

A panel consisting of a scholar, librarians, and a database producer will discuss the development of African American Studies within the academy and librarians as collaborators in the research process. The panel will explore the possibility of research initiatives and professional service opportunities that foster collaboration. Educational opportunities such as degree programs, study tours, and summer institutes pertinent to African American Studies will be highlighted. An overview of training and professional development activities of African American Studies librarians in libraries and libraryrelated organizations will be discussed. A product specialist will demonstrate the newly developed Black Studies Online database. Speakers: Charles P. Henry, chair and professor of African American Studies, University of California at Berkeley; Jessie Carney Smith, university librarian, Fisk University; Kristin Franckiewicz, ProQuest product specialist; Stanton F. Biddle, professor, Baruch College, Library; Moderator: Sylvia Curtis, reference librarian, University of California at Santa Barbara. 


\section{ACRL Arts and Literatures in English}

2:00 p.m.-4:00 p.m., Track B: Information Services

\section{The Beat Generation: Collaboration and Community}

The Beat Generation created a rich legacy of books, periodicals, polemical and creative ephemera, music, and art works that have enriched libraries, museums, bookstores, and publishers, and that permanently altered the cultural landscape of America. These writers and artists collaborated in poetry readings, jazz, writing-inspired dance and films, and often in their personal lives. Four speakers will describe (with slides and video) the cultural community of the Beat Generation's literature, visual arts, and dance. Speakers: Paul Karlstrom, director, West Coast Research Center, Archives of American Art, Huntington Library; Ann Charters, professor, University of Connecticut; Janice Ross, professor, Stanford University, Dance Division; Bill Morgan, author, bibliographer, and editor; Michael McClure, author.

\section{ACRL Distance Learning Section (DLS)}

\section{2:00 p.m. $-4: 00$ p.m., Track B: Information Services}

\section{Integrate, Separate, or Outsource? Models for Distance Learning Services}

The Distance Learning Section hosts a discussion about organizing services to online and off-campus students. Alexander Slade, co-author of Library Services for Open and Distance Learning, presents the issues. Steve Schafer discusses integrated services drawing on Athabasca University's 30 years of distance education. Anne Marie Casey details 25 years of Central Michigan University's Off-Campus Library Services. Kim Dority outlines Jones International University's inter-institutional outsourcing services. Speakers: Alexander (Sandy) Slade, head, Document Supply Services, University of Victoria Library; Steve Schafer, director, Library, Athabasca University; Anne Marie Casey, director, OffCampus Library Services, Central Michigan University; Kim Dority, vice-president, e-global library, Jones International University, LTD.

\section{ACRL Law and Political Science Section (LPSS)}

2:00 p.m.-4:00 p.m., Track B: Information Services

\section{New Technologies, New Opportunities: Collaborating with Faculty}

This program examines the innovative use of new educational technologies to improve information access. A panel of two faculty members and one librarian will examine the methods and importance of collaboration when incorporating courseware technology and the library into the classroom. In addition to a general discussion of faculty/librarian collaboration, we will look at a specific example in the use of WebCT for collaboration and explore issues related to distance education and technology. Speakers: Frada Mozenter, reference librarian, University of North Carolina at Charlotte; Teodora Delorenzo, professor of Political Science, California State University at Chico; Artemus Ward, professor of Political Science, California State University at Chico.

\section{ACRL University Libraries Section (ULS)}

2:00 p.m.-4:00 p.m., Track E: Advocacy

\section{Outside/In: Seeing Ourselves as Others See Us}

Professionals outside librarianship have much-needed insight into information services required for success in academic libraries today. A panel of distinguished speakers will discuss how "outsiders" to the world of librarianship perceive the changing world of academic information. Speakers: Stephanie Bangert, assistant director, Western Association of Schools and Colleges; John Seely Brown, chief scientist, Xerox and coauthor of The Social Life of Information; Kathryne Reeves, director of product marketing, Questia Media. 


\section{ACRL Media Resources Committee}

2:00 p.m.-4:00 p.m., Track A: Leadership

\section{Media Resources 101: A Primer}

Media resource programs have changed dramatically over the years, most noticeably in collections, services, and user expectations. Our panel of media librarians will use the ACRL "Guidelines for Media Resources in Academic Libraries" (http://www.ala.org/acrl/ guides/medresg.html) as a springboard for their remarks as they share their personal experiences in planning, budgeting, staffing, and collection development. The ALA Video Round Table's Sunday, June 17, 2:00-4:00 p.m. program, The Reel Nitty Gritty, will provide a great segue for continued practical discussion in media librarianship. Speakers: Kristine R. Brancolini, director, Digital Library Program, Indiana University; Rick E. Provine, technology librarian, DePauw University; Gary Handman, director, Media Resources Center, University of California-Berkeley; Randy Pitman, chair, ALA Video Round Table, Publisher/Editor, Video Librarian; Moderator: Mary S. Konkel, head of cataloging, University of Akron.

\section{Sunday, June 17}

\section{ACRL Anthropology and Sociology Section (ANSS)}

9:00 a.m. $-12: 30$ p.m., Track G: Issues \& Updates

\section{Social Movements, Marginalized Groups and the Internet: Issues for Librarians and Researchers}

This program will discuss some of the implications and effects of using the Internet as a tool for social movements and for increasing visibility of marginalized or indigenous groups. The Internet has become an important tool for disseminating information and organizing support on an international level. Researchers and scholars are working with many marginalized populations and indigenous groups to establish Internet access, digitize resources and help create web pages. This panel will highlight several projects and what librarians need to know to reach the evolving needs of information seekers in the rapidly changing online environment. Speakers: Marc Becker, professor of Latin American history and founder of NativeWeb, Truman State University; Harry Cleaver, professor of Economics at University of Texas at Austin; Patti Mallin, PeaceNet coordinator, Institute of Global Communications; Itibari Zulu, UCLA Center for African American Studies.

\section{ACRL College Libraries Section (CLS)}

9:00 a.m. $-12: 30$ p.m., Track C: Digital Library

\section{Virtual Space/Virtuous Place: College Libraries in the $21^{\text {st }}$ Century}

As college libraries develop electronic book collections to add to the number of electronic resources readily available on our constituents' desktops, they must also continue to provide a physical place where the values of intellectual curiosity, freedom of inquiry, and cultural awareness serve to promote a well-informed society. This program will suggest new metaphors for integrating the traditional college library, a virtuous place of intellectual discourse and cultural activity, with newer virtual electronic learning environments. Speakers: Joyce Ray, director, Office of Library Services, Institute of Museum and Library Services; Stephanie Bangert, assistant director, The Western Association of Schools and Colleges; Deanna B. Marcum, president, Council on Library and Information Resources; Sam DeMas, college librarian, Gould Library; LaVerna Saunders, dean, Library Administration. 


\section{ACRL Publications and Research Committees}

11:00 a.m.-12:30 p.m., Track A: Leadership

Getting Published \& What It Takes: A Conversation with Editors \& Authors

Many academic librarians seeking promotion or tenure are required to publish but are unsure of the criteria of a publishable paper. Four editors and two established authors will address issues such as writing style, research methodology, and peer review. Each panel member will offer useful advice to budding and prospective authors. The information provided in this program will help librarians approach the research/ publication process with greater confidence and likelihood of success. Speakers: Gloriana St. Clair, editor, Portal; Peter Hernon, editor, Journal of Academic Librarianship; Mary Ellen Davis, editor, College \& Research Libraries News; Julie Hurd, University of Illinois at Chicago; Karen Schmidt, University of Illinois at Urbana-Champaign; Donald Riggs, editor, College \& Research Libraries.

\section{ACRL Asian, African and Middle Eastern Section (AAMES)}

2:00 p.m. $-4: 00$ p.m., Track C: Digital Library

\section{Unicode: Representing the World's Languages Online: Trends and Applications}

Is Unicode Greek to you? Come explore how Unicode is revolutionizing accessibility and usability of languages in the online library world with our panel of experts from the Unicode Consortium, OCLC, RLG, and VTLS, Inc. What will it mean for your patrons and for how you do your own work? Our panel will guide you through these changes and how they are affecting bibliographic utilities, indexing and abstracting services, online catalogs, and librarianship. Speakers: Mark Davis, president, Unicode; Andrew Wang, OCLC Asia/ Pacific; Walt Crawford, Research Libraries Group; Vinod Chachra, president, VTLS, Inc.

\section{ACRL Education and Behavioral Sciences (EBSS)}

2:00 p.m.- 5:30 p.m., Track B: Information Services

Old Friends, New Partners: Academic Libraries Redefine K-12 Outreach

Academic libraries are forging new partnerships with the K-12 community to expand traditional outreach efforts in library instruction and to develop new outreach services and collaborative projects. A panel of speakers will address trends and issues in developing successful outreach models. Examples of specific outreach programs will also be featured, including a discussion of program benefits/challenges, planning, funding, and evaluation. Poster sessions highlighting innovative $\mathrm{K}-12$ outreach projects will follow the program. Speakers: Sandra Millard, assistant director for Library Public Services and program director, UDLib/SEARCH, University of Delaware Library; Stephanie Sterling-Brasley, instructional outreach coordinator, College Library, University of California Los Angeles; Gloria Rhodes, multicultural outreach librarian, California State University, San Marcos Library.

\section{ACRL Instruction Section (IS)}

2:00 p.m.- 4:00 p.m., Track B: Information Services

Partners in Progress: Using Campus Partnerships to Promote Information Literacy

The decision to integrate information literacy concepts and competencies on an institutional level begins with a common goal and a shared philosophy, and often involves institution-wide cultural and curricular changes. Larry Hardesty will discuss the nature and implications of such changes in the context of library and faculty cultures, while Patricia lannuzzi and Sally Murphy will share successes and challenges encountered while implementing information literacy programs on their campuses. Speakers: Larry Hardesty, library director, Austin College; Patricia lannuzzi, associate university librarian and director, Doe-Moffitt Libraries, University of California, Berkeley; Sally Murphy, G.E. coordinator, California State University, Hayward. 


\section{LITA/ACRL Technology and the Arts Committee/IG}

2:00 p.m.-4:00 p.m., Track C: Digital Library

\section{Electronic Poetry Salon}

Many poets have evolved from quill pens to electrons, using the Internet, computer graphics, audio, video, multimedia, and wireless technologies to create, enhance, and share their work. A variety of poets and editors will present samples of their work and discuss how it was created. They will explore online journals and e-zines, multimedia, collaborative and distributive poetry, and how libraries can be a part of this creative community. Speakers: Bowerbird, performancepoetry.com; Jo Falcon, Exploratorium and McClure-Manzarek Metasite; Loss Pequeno Glazer, SUNY-Buffalo Electronic Poetry Center; Ian Moore, National Poetry Association and Cine-(E) Poetry Festival; Ken Siegmann, Poetry USA; Dylan Tweney, Tinywords.Com; Aaron Yamaguchi, X-Studios and Six Gallery.

\section{ACRL Slavic and East European Section (SEES), SEES Committee on Continuing Education on Slavic and East European Libraries}

2:00 p.m.-4:00 p.m., Track B: Information Services

\section{Slavic Collections in the San Francisco Bay Area and Their Impact On the Intellectual, Cultural and Economic Life of the Local Community}

The San Francisco Bay Area has one of the most important concentrations of materials on every aspect of Slavic and East European studies in the world. The Slavic Collections at Stanford University, the Hoover Institution, the University of California at Berkeley, and the San Francisco Public Library, to mention only a few, are rich in material in every format: books, manuscripts, archival material, paintings, posters, and films. The geographic area covers almost every East European country. Contribution to Slavic studies in the San Francisco Bay Area community is significant. The magnitude of these vast resources, which is estimated at over one million imprints in Russian/Soviet and East European languages and subjects, is available to scholars and the local community in the Bay Area. Speakers: Allan Urbanic, librarian for Slavic Collections, University of California-Berkeley; Carol Leadenham, assistant archivist for reference, Hoover Institution Archives; Sharon Wilensky, librarian for Slavic Collections, San Francisco Public Library, Richmond Branch.

\section{ACRL Rare Books and Manuscripts Section (RBMS)}

\section{2:00 p.m.-5:30 p.m., Track F: Information Access}

\section{Collecting the Twentieth Century: the Roles of Scholars and Rare Book and Special Collections Librarians}

As they enter the $21^{\text {st }}$ century, rare book and special collections librarians are faced with collecting and interpreting 20th-century materials and formats, which became increasingly diverse and non-traditional as the century progressed. Scholars of the period face similar problems as they attempt to interpret vast, complicated, and oftentimes global issues. This program investigates the challenges, opportunities, and responsibilities of librarians and scholars in shaping and using special collections of 20th-century materials. Speakers: Elena S. Danielson, archivist of the Hoover Institution, Stanford University; second speaker TBA. 


\section{Monday, June 18}

\section{ACRL Science and Technology Section (STS)}

9:00 a.m. $-12: 30$ p.m. Track: Other Programs, Events, and Functions

\section{Quantum Leaps by Decade: Forty Years of Science Librarianship}

In celebration of the $40^{\text {th }}$ anniversary of the Science $\&$ Technology Section, this program highlights the major contributions to science librarianship by promoting relationships with publishing, educational leaders and the scientific community, industry, allied associations while preparing for its future. By decade, prominent speakers will address developments such as:

- 1960s: birth of citation analysis

- 1970s: partnership for education, and new forms of scholarly communication

- 1980s: the digital age

- 1990s: the era of networking and building new communities

- new millennium: linking the past with the future-what course are we on?

Speakers: Eugene Garfield, information scientist \& chairman emeritus, Institute for Scientific Information (ISI); Marian Cleeves Diamond, professor of Integrative Biology, University of California-Berkeley; John Warnock, president, Adobe Systems and Octavo Publishing; Clifford Lynch, executive director, Coalition for Networked Information; Eugenie Prime, director of libraries, Hewlett Packard.

\section{ACRL Western European Studies Section (WESS)}

\section{9:00 a.m.-10:30 a.m. Track F: Information Access}

\section{Exploding Canons: Including the Voices of Spain's Excluded Communities} Since the death of Francisco Franco, Spain has joined the European community and has become more open to regional, political, ethnic, and gender diversity. Among the groups becoming more noticeable are women, gay and lesbian persons, and immigrants. The WESS program for 2001 will address issues including these communities, once excluded, in our libraries' coverage of the Iberian peninsula. Speakers: Ramon Abad, librarian, Cervantes Institute, New York; Silvia Bermudez, associate professor of Spanish, Department of Spanish and Portugese, University of California, Santa Barbara; David William Foster, chair, Department of Spanish and Portuguese, Arizona State University.

\section{ACRL Women's Studies Section, SRRT/Feminist Task Force}

\section{9:00 a.m.-12:30 p.m., Track A: Leadership}

\section{Women Moving Mountains: Women and Organizations}

Kathryn Deiss discusses issues for women in leadership and organizational development from the perspective of years of training librarians for the Association of Research Libraries and the Chicago Library System. She will raise issues and lead a discussion surrounding the impact of gender on leadership in organizations, on opportunity within organizations, on room for creativity in organizations, and on influence in organizations. She will address the influence/confluence of the rise of Women's Studies, the Women's Movement, and focus on understanding gender in the workplace. Additionally, presentation of WSS Awards-ACRL WSS Award for Career Achievement in Women's Studies Librarianship sponsored by Greenwood Publishing Group to Sarah Pritchard and ACRL WSS Award for Significant Achievement in Women's Studies Librarianship sponsored by Routledge Press to Marilyn Dunn. Speaker: Kathryn Deiss, director for Education \& Training, Chicago Library System. 


\section{Special Events/Tours}

Friday, June 15, 6:30-9:30 p.m.

College Libraries Section

\section{CLS Dinner}

Canton Seafood \& Dim Sum Restaurant, 633 Folsom St., \$38. Contact Susan Richards for more information, susan.t.richards@|awrence.edu.

\section{Friday, June 15, 6:00-10:00 p.m.}

Instruction Section

\section{IS Dinner}

Gabbiano's Restaurant, One Ferry Plaza, $\$ 36.75$. Contact Jennifer Laherty for more information, jlaherty@csuhayward.edu.

\section{Sunday, June 17 \& Tuesday, June 19, 2001}

Science \& Technology Section

\section{STS 40th Anniversary Celebration}

As part of the festivities, several special events will take place reflecting on the work of the section:

- The Institute for Scientific Information (ISI) will honor STS members and Friends at an invitation-only reception on Sunday, June 17 . Contact

blanche.callazo@isinet.com for details;

- All-day field trip to the Stanford Linear Accelerator Center in Palo Alto on Tuesday, June 19. Reservations are required and can be made by visiting the Web site, http:// www.slac.stanford.edu/library/sts/ststour.html.

\section{Sunday, June 17, Noon-1:30 p.m.}

\section{ARTS Section}

\section{No-Host Lunch}

A convivial event for current and new members to dine and converse on arts-related issues. Cost: Varies; each person pays for his or her own meal. Restaurant: To be arranged. Contact Lorelei Tanji for more information, Ltanji@uci.edu.

\section{Sunday, June 17, 6:00-9:00 p.m.}

Western European Studies Section

\section{WESS Cruise}

Pacific Marine Yachts, Pier 9, East Marina, \$26. Contact Beth Remak for more

information, remak@cats.ucsc.edu. 


\section{Meetings}

Editor's note: This list was current as C\&RL News went to press. Be sure to check the program book for the final schedule and location of meetings.

\section{ACRL Board of Directors}

First meeting: Saturday, June 16, 2:00-5:30 p.m. Second meeting: Tuesday, June 19, 1:00-4:00 p.m.

\section{ACRL General}

ACRL Academic/Research Librarian of the Year Award Reception: Monday, June 18, 4:30-6:00 p.m.

Chapters Council: Sunday, June 17, 8:30-11:00 a.m.

Leadership Council: Friday, June 15, 2:00-4:00 p.m. New Leader Orientation: Friday, June 15, 12:002:00 p.m.

President's Program: Monday, June 18, 2:00-4:00 p.m. Topic: "The Creative Genius of Community" Sections Council: Friday, June 15, 4:30-5:30 p.m.

\section{ACRL Dívisional Committees}

Academic Librarians Status: Sunday, June 17, 8:3011:00 a.m.; Monday, June 18, 8:30 a.m.-12:30 p.m.

ACRL/SPARC Forum: Saturday, June 16, 11:00 a.m.12:30 p.m. Topic: "Outward Bound: Effecting Change in Scholarly Communication from Outside the Library"

Best Practices Project Team: Monday, June 18, 9:00 a.m. $-5: 30$ p.m.

Budget and Finance: Saturday, June 16, 8:30 a.m.12:30 p.m.; Monday, June 18, 8:30 a.m.-12:30 p.m.

Bylaws Committee: Saturday, June 16, 9:30-11:00 a.m.; Monday, June 18, 9:30-11:00 a.m.

Conference Program Planning-Atlanta, 2002: Saturday, June 16, 8:00-9:00 a.m.

Conference Program Planning-Toronto, 2003: Sunday, June 17, 4:30-5:30 p.m.

Copyright: Sunday, June 17, 8:30 a.m.-12:30 p.m.

Effective Practices: Monday, June 18, 9:30 a.m-12:30 p.m.

Ethics: Tuesday, June 19, 9:30 a.m.-12:30 p.m.

Government Relations: Meeting: Saturday, June 16, 2:00-4:00 p.m.; Monday, June 18, 9:30 a.m.12:30 p.m.; ACRL Advocacy Circles: Sunday, June 17. 11:00 a.m.-12:30 p.m.
Information Literacy Advisory: Sunday, June 17. 11:30 a.m. $-12: 30$ p.m.

Information Literacy Competency Standards Task Force: Sunday, June 17, 8:30-11:00 a.m.; Monday, June 10, 9:30-11:00 a.m.

Institute for Information Literacy Advisory: Friday, June 15, 9:00 a.m.-5:30 p.m; Sunday, June 17, 11:30 a.m.-12:30 p.m.

Institute for Information Literacy (IIL) Faculty: Thursday, June 14, 8:00 a.m.-5:30 p.m.

Intellectual Freedom: Saturday, June 16, 2:00-4:00 p.m.

International Relations: Sunday, June 17, 8:3011:00 a.m.

Leadership Council: Friday, June 15, 2:00-4:00 p.m.

Liaisons Roundtable: Saturday, June 16, 8:3011:00 a.m.

Media Resources: Meeting: Sunday, June 17, 9:3011:00 a.m.; Program: Saturday, June 16, 2:004:00 p.m. "Media Resources 101: A Primer"

Membership: Sunday, June 17, 2:00-4:00 p.m.

National Conference Executive CommitteeCharlotte: Saturday, June 16, 11:30 a.m.-1:30 p.m.

National Conference Subcommittees-Charlotte: Monday, June $18,8: 30$ a.m. $-12: 30$ p.m.

Nominations 2002: Saturday, June 16, 9:30-11:00 a.m.

President's Program Planning-2002: Saturday, June 16, 9:00 a.m.-5:30 p.m.

President's Program Planning-2001: Monday, June 18, 9:30 a.m.-12:30 p.m.

Professional Development: Saturday, June 16, 9:30-11:00 a.m.

Publications: Saturday, June 16, 8:00-9:00 a.m.; Monday, June 18, 8:30-11:00 a.m. Program (Joint program with Research): Sunday, June 17, 11:00 a.m.-12:30 p.m., Topic: "Getting Happily Published"

Racial and Ethnic Diversity: Saturday, June 16, 9:30 a.m. $-12: 30$ p.m.

Research: Meeting: Saturday, June 16, 11:30 a.m.1:00 p.m.; Program (Joint program with Publications): Sunday, June 17, 11:00 a.m.-12:30 p.m., Topic: "Getting Happily Published"

Scholarly Communications Task Force: Sunday, June 17, 8:30-11:00 a.m; SPARC Forum: Saturday, June 16, 11:00 a.m.-12:30 p.m.

Standards and Accreditation: Friday, June 5, 8:0010:00 p.m. 
Statistics: Friday, June 15, 4:30-5:30 p.m.

Teaching and Learning with Technology (TLTC)

Task Force: Monday, June 18, 4:30-5:30 p.m.

\section{ACRL Chapters}

Chapters Council: Sunday, June 17, 8:30-11:00 a.m.

\section{ACRL Editorial Boards}

Choice: Sunday, June 17, 8:30-11:00 a.m.

Choice Reviews Online Focus Group: Monday, June 18, 7:30-9:00 a.m.

College \& Research Libraries: Saturday, June 16, 11:30 a.m.-12:30 p.m.

College \& Research Libraries News: Sunday, June 17, 2:00-4:00 p.m.

New Publications Advisory Board: Sunday, June 17, 11:30 a.m. $-12: 30$ p.m.

Publications in Librarianship: Saturday, June 16, 2:00-4:00 p.m.

RBM Editorial Board: Sunday, June 17, 8:30-11:00 a.m.

\section{ACRL Sections}

Sections Council: Friday, June 15, 4:30-5:30 p.m.

\section{African American Studies Librarians Section}

Program: Saturday, June 16, 2:00-4:00 p.m "African American Studies and Librarianship: A Natural Relationship"

Executive: Saturday, June 16, 9:30-11:00 a.m.

General Membership: Saturday, June 16, 4:30-5:30 p.m.

Cataloging Issues Discussion Group: Sunday, June 17, 9:30-11:00 a.m.

Standing Committees: Saturday, June 16, 8:009:00 a.m.

\section{Asian, African, and Middle Eastern Section}

Executive and Committee: Saturday, June 16, 9:30 a.m. $-12: 30$ a.m.

Program: Sunday, June 17, 2:00-4:00 p.m. Topic: "Unicode: Representing the World's Languages Online: Trends and Applications"

General Membership: Sunday, June 17, 4:30-5:30 p.m.

Nominating: Friday, June 15, 11:30 a.m.-12:30 p.m.
Program Planning: Friday, June 15, 11:30 a.m.12:30 p.m.

\section{Anthropology and Sociology Section}

Program: Sunday, June 17, 9:00 a.m.-12:30 p.m. Topic: "Social Movements, Marginalized Groups and the Internet: Issues for Librarians and Researchers"

ANSS 30th Anniversary Celebration: Sunday, June 17, 12:30-1:30 p.m.

Executive: Saturday, June 16, 8:00-9:00 a.m.; Monday, June 18, 9:30 a.m.-12:30 p.m.

Anthropology Librarians Discussion Group: Sunday, June 17, 4:30-5:30 p.m.

Bibliography: Saturday, June 16, 2:00-5:30 p.m.

Conference Program Planning-San Francisco, 2001: Sunday, June 17, 8:00-9:00 a.m.

Conference Program Planning-Atlanta, 2002: Monday, June 18, 8:00-9:00 a.m.

Liaison: Saturday, June 16, 9:30-11:00 a.m.

Membership: Sunday, June 17, 2:00-4:00 p.m.

Nominating 2002: Monday, June 18, 8:009:00 a.m.

Publications: Saturday, June 16, 9:30-11:00 a.m.

Review and Planning: Saturday, June 16, 9:3011:00 a.m

Sociology Librarians Discussion Group: Saturday, June 16, 11:30 a.m.-12:30 p.m.

\section{Arts Section}

Program (Joint program with LES): Saturday, June 16, 2:00-4:00 p.m. Topic: "The Beat Generation: Collaboration and Community"

Program (Joint program with LITA/Technology in the Arts): Sunday, June 17, 2:00-4:00 p.m.

Executive Committee and Membership: Sunday, June 17, 9:00-11:00 a.m.

All Committees: Saturday, June 16, 9:30 a.m.-12:30 p.m.

Dance Librarians Discussion Group: Sunday, June 17, 4:30-5:30 p.m.

Performing Arts Librarians Discussion Group: Sunday, June 17, 8:00-9:00 a.m.

\section{Community and Junior College Libraries Section}

Program: Saturday, June 16, 9:30 a.m.-12:30 p.m. Topic: "Assistive Technologies: The Real Issues Behind Access"

Executive: Sunday, June 17, 11:30 a.m.-12:30 p.m.; Monday, June 18, 8:30-11:00 a.m. 
All Committees (Bibliographic Instruction, Library/Media Technician Training, Library Resources Review, Membership/Communication, Planning and Procedures, Research and Publications, Technology): Sunday, June 17 , 8:30-11:00 a.m.

CJCLS/NCLR Joint Discussion Group: Sunday, June 17, 2:00-4:00 p.m.

Conference Program Planning-Atlanta, 2002: Monday, June 18, 11:30 a.m.-12:30 p.m.

Membership: Saturday, June 16, 8:00- 9:00 a.m.

Nominating 2002: Sunday, June 17, 2:004:00 p.m.

Standards: Friday, June 15, 2:00-4:00 p.m.

\section{College Libraries Section}

Program: Sunday, June 17, 9:00 a.m.-12:30 p.m. Topic: "Virtual SpaceNirtuous Place: College Libraries in the 21 st Century"
Executive: Saturday, June 16, 9:00-11:00 a.m.; Tuesday, June 19, 8:30-11:00 a.m.

Business: Sunday, June 17, 9:00-9:30 a.m.

CLIP Notes: Saturday, June 16, 11:30 a.m.-12:30 p.m.

College Librarians and Staff Discussion Group: Sunday, June 17, 4:00-5:00 p.m.

College Library Directors Discussion Group: Sunday, June 17, 2:00-4:00 p.m.

Communications: Saturday, June 16, 11:30 a.m.12:30 p.m

Conference Program Planning-San Francisco, 2001: Saturday, June 16, 11:30 a.m.-12:30 p.m.

Conference Program Planning-Atlanta, 2002: Saturday, June 16, 9:30-11:00 a.m.; Monday, June 18, 9:30-11:00 a.m.

Continuing Education: Monday, June 18, 9:3011:00 a.m.

Leadership: Monday, June 18, 9:30-11:00 a.m

Membership: Monday, June 18, 8:00-9:00 a.m.

\section{Discussion Groups}

(All section discussion groups are listed with their sections.)

Alliances for New Directions in Teaching and Learning: Saturday, June 16, 2:00-4:00 p.m.

Australian/Canadian/New Zealand Studies: Sunday, June 17, 11:30 a.m.-12:30 p.m. Topic: "Australian Literary Studies: Two Collections Compared"

Consumer and Family Studies: Sunday, June 17 , 4:30-5:30 p.m. Topic: "Statistical Web Sites and Data Sets Covering the Consumer and Family Studies Discipline (consumer expenditures, food expenditures, population characteristics, nutrition/food composition data, etc.)"

Criminal Justice/Criminology: Saturday, June 16, 4:30-6:00 p.m.

E-Text: Sunday, June 17, 2:00-4:00 p.m. Topic: "Using XSL: An Introduction"

Electronic Reserves: Sunday, June 17, 8:30-11:00 a.m. Topic: "Multimedia Electronic Reserves"

Heads of Public/Reader Services: Sunday, June 17, 4:30-5:30 p.m. Topic: "Personalized Services to Library Users"

Library and Information Science Collections: Sunday, June 17, 9:30-11:00 a.m.

Library Development Officers: Sunday, June 17, 8:30-11:00 a.m. Topic: "Raising Money for the Academic Library from the Annual Fund Director's Perspective"

Medium-Sized Academic Libraries Discussion Group: Monday, June 18, 9:30-11:30 a.m. Topic: "Using ACRL Standards \& Guidelines as an Assessment Tool"
MLA International Bibliography in Academic Libraries: Saturday, June 16, 9:30 a.m.-12:30 p.m. Topic: Comparison of MLAIB Online Vendors/Interfaces with Representatives of OCLC, Ovid, and Silver Platter

Personnel Administrators and Staff Development Officers: Saturday, June 16, 9:30-11:00 a.m.; Sunday, June 17, 9:30-11:00 a.m. Topic: "The Status of Library Recruitment and Retention;" Sunday, June 17, 4:30-5:30 p.m. Topic: Specia/ Session: Considering Creation of a Forum for the Discussion of Issues and Topics that Include Facilitative Leadership, Organizational Learning, and Organizational Development

Philosophy, Religion, and Theology: Sunday, June 17, 2:00-4:00 p.m. Topic: "Digital Initiatives in Philosophy Publishing"

Popular Culture in Libraries: Sunday, June 17, 4:30-5:30 p.m. "Popular Culture MaterialsOnce We Get Them, What Can We Do With Them?"

Research: Friday, June 15, 2:00-4:00 p.m. Topic: "How to Balance Research, Publishing, Professional Service, and the Job as an Academic Librarian?"

Team-Based Organizations: Saturday, June 16 , 9:30-11:00 a.m. Topic: "Issues in Team-Based Libraries"

Undergraduate Librarians: Monday, June 18, 8:30-11:00 a.m. 
Orientation for New Officers and Chairs: Saturday, June 16, 8:30-9:00 a.m.

Research for College Librarianship: Monday, June 18, 9:30-11:00 a.m.

Standards: Saturday, June 16, 11:30 a.m.-12:30 p.m.

\section{Distance Learning Section}

Program: Saturday, June 16, 2:00-4:00 p.m. Topic: "Integrate, Separate, or Outsource: Models for Distance Learning Library Services"

Executive: Sunday, June 17, 2:00-4:00 p.m.

All Committees: Sunday, June 17, 8:30-11:00 a.m.

General Membership Discussion Group: Monday, June 18, 8:30-11:00 a.m.

\section{Education and Behavioral Sciences Section}

Program: Sunday, June 17, 2:00-5:30 p.m. Topic: "Old Friends, New Partners: Academic Libraries Redefine K-12 Outreach"

Executive: Friday, June 15, 7:00-9:00 p.m.

Advisory Council: Sunday, June 17, 9:30 a.m.12:30 p.m.

Conference Program Planning-Atlanta, 2002: Sunday, June 17, 5:00-6:00 p.m.

Conference Program Poster Sessions: Sunday, June 17, 2:00-5:30 p.m.

Consolidated Committees (Distinguished Librarian Award, Government Policy, Instruction for Educators, Membership \& Orientation, Publications \& Communications, Reference Sources \& Services): Saturday, June 16, 9:30 a.m. $-12: 30$ p.m.

Curriculum Materials Center Directory, Revisions (Ad Hoc Committee): Saturday, June 16, 1:003:00 p.m.

Curriculum Materials Centers Standards/Guidelines (Ad Hoc Committee): Saturday, June 16, 8:00-11:00 a.m.

Digital Publication of the CMC Management Guide (Ad Hoc Committee): Saturday, June 16, 2:00-4:00 p.m.

Gerontology: Saturday, June 16, 11:30 a.m.-12:30 p.m.

Historical Textbook and Curriculum Collections Directory (Ad Hoc Committee): Saturday, June 16, 2:00-4:00 p.m.

New Leader Orientation: Sunday, June 17, 8:009:00 a.m.

Psychology/Psychiatry: Saturday, June 16, 8:3011:00 a.m.
Publications \& Communications Executive Group: Saturday, June 16, 8:00-9:00 a.m.

Social Work/Social Welfare: Friday, June 15, 4:306:30 p.m.

\section{Instruction Section}

Program: Sunday, June 17, 2:00-4:00 p.m. Topic: "Partners in Progress: Using Campus Partnerships to Promote Information Literacy"

Dinner: Friday, June 15, 6:00-9:00 p.m.

Executive: Saturday, June 16, 8:00-9:00 a.m.; Tuesday, June 19, 9:30 a.m.-12:30 p.m.

Advisory Council: Saturday, June 16, 9:30-11:00 a.m.; Monday, June 18, 9:30-11:00 a.m.

Awards (closed): Saturday, June 16, 2:00-4:00 p.m.

Communication: Saturday, June 16, 2:004:00 p.m.

Conference Program Planning-San Francisco, 2001: Saturday, June 16, 2:00-4:00 p.m.

Conference Program Planning-Atlanta, 2002: Meeting: Sunday, June 17, 8:00-9:00 a.m.

Education for Library Instructors: Saturday, June 16, 2:00-4:00 p.m.

Emerging Technologies in Instruction: Saturday, June 16, 2:00-4:00 p.m.

Immersion Alumni: Sunday, June 17, 9:30-11:00 a.m.

Instruction for Diverse Populations Committee: Saturday, June 16, 2:00-4:00 p.m.

Management of Instruction Services: Saturday, June 16, 2:00-4:00 p.m.

Membership: Saturday, June 16, 2:00-4:00 p.m.

New Leadership Orientation: Saturday, June 16, 11:30 a.m. $-12: 30$ p.m.

Nominating 2002: Saturday, June 16, 2:00-4:00 p.m. (closed)

Planning: Saturday, June 16, 2:00-4:00 p.m.

Policy: Saturday, June 16, 2:00-4:00 p.m.

Preconference: Friday, June 15, 8:30 a.m. $-5: 00$ p.m. Topic: "How to Keep from Glazing Over When You Hear the Word Assessment; Realistic Strategies for the Library Instruction Community"

Preconference Program Planning, San Francisco, 2001: Saturday, June 16, 2:00-4:00 p.m.

Preconference Program Planning-Atlanta, 2002: Saturday, June 16, 2:00-4:00 p.m.; Monday, June 18, 8:00-9:00 a.m.

Research and Scholarship: Saturday, June 16, 2:00-4:00 p.m.

Research Committee Discussion Group: Saturday, June 16, 4:30-5:30 p.m.

Teaching Methods: Saturday, June 16, 2:00-4:00 p.m. 


\section{Law and Political Sciences Section}

Program: Saturday, June 16, 2:00-4:00 p.m. Topic: "New Technologies, New Opportunities: Collaborating with Faculty"

All Committees: Sunday, June 17, 9:30 a.m.-12:30 p.m.

Historians Discussion Group: Sunday, June 17, 8:00-9:00 a.m.

Marta Lange/CQ Award Committee: Sunday, June 17. 9:30 a.m.-12:30 p.m. (closed); Luncheon (closed): Saturday, June 16, 12:00-1:30 p.m.

\section{Literatures in English}

Program (Joint Program with ARTS): Saturday, June 9, 2:00-4:00 p.m. Topic: "The Beat Generation: Collaboration and Community"

Executive: Saturday, June 16, 9:30-11:00 a.m.; Monday, June 18, 11:30 a.m. $-12: 30$ p.m.

All Committees: Monday, June 18, 8:30-11:00 a.m. Membership: Sunday, June 17, 2:004:00 p.m.

19th Century Discussion Group: Saturday, June 16, 11:30 a.m. $-12: 30$ p.m.

Nominating: Monday, June 18, 9:30-11:00 a.m.

Reference Discussion Group: Sunday, June 17, 9:30-11:00 a.m

Research Competencies Discussion Group: Sunday, June 17, 11:30 a.m.-12:30 p.m.

\section{Rare Books and Manuscripts Section}

Program: Sunday, June 17, 2:00-5:30 p.m. Topic: "RBMS: Collecting the Twentieth Century"

Executive: Monday, June 18, 8:30 a.m.-12:30 p.m. Bibliographic Standards: Saturday, June 16, 8:30 a.m.-12:30 p.m.; Sunday, June 17, 8:30 a.m.12:30 p.m.

Budget and Development: Saturday, June 16, 2:00-4:00 p.m.

Conference Development: Sunday, June 17, 8:3011:00 a.m.

Conference Program Planning-Atlanta, 2002: Sunday, June 17, 9:30-11:00 a.m.

Curators and Conservators Discussion Group: Sunday, June 17, 8:30-11:00 a.m.

Exhibition Catalogue Awards: Saturday, June 16, 8:30 a.m.-12:30 a.m. (closed)

Hearing on Guidelines for Borrowing and Loaning Special Collections Materials for Exhibition: Saturday, June 16, 4:30-5:30 p.m. Information Exchange: Sunday, June 17, 4:30-5:30 p.m.
Manuscripts and Other Formats Discussion Group: Saturday, June 16, 8:30-11:00 a.m.

MARC for Special Collections Discussion Group: Sunday, June 17, 11:30 a.m.-12:30 p.m.

Membership and Professional Development: Saturday, June 16, 2:00-4:00 p.m.

Nominating: Saturday, June 16, 11:30 a.m.-12:30 p.m. (closed)

Preconference Program Planning-Atlanta, 2002: Saturday, June 16, 8:30-11:00 a.m.

Preconference Program Planning-Toronto, 2003: Saturday, June 16, 11:30 a.m.-12:30 p.m.

Public Services Discussion Group: Saturday, June 16, 8:30-11:00 a.m.

Publications: Saturday, June 16, 2:00-4:00 p.m.

Security: Saturday, June 16, 2:00-4:00 p.m.

Seminars: Saturday, June 16, 2:00-4:00 p.m.

\section{Slavic and East European Section}

Program: Sunday, June 17, 2:00-4:00 p.m. Topic: "Slavic Collections in the San Francisco Bay Area"

Executive: Monday, June 18, 9:30-11:00 a.m.

Automated Bibliographic Control: Saturday, June 16, 9:30-11:00 a.m.

Conference Program Planning-Atlanta, 2002: Sunday, June 17, 8:00-9:00 a.m.

Continuing Education: Saturday, June 16, 11:30 a.m. $-12: 30$ p.m.

Electronic Resources: Sunday, June 17, 11:30 a.m12:30 p.m.

Membership: Sunday, June 17, 4:30-5:30 p.m.

Newsletter: Sunday, June 17, 9:30-11:00 a.m.

Nominating: Saturday, June 16, 8:00-9:00 a.m. (closed)

Preservation: Saturday, June 16, 2:00-4:00 p.m.

\section{Science and Technology}

\section{Section}

Program: Monday, June 18, 9:00 a.m.-12:30 p.m. Topic: “Quantum Leaps by Decades: Forty Years of Science Librarianship"

College Science Librarians Discussion Group: Sunday, June 17, 11:30 a.m.-12:30 p.m.

Comparison of Science and Technology Libraries: Saturday, June 16, 8:30-11:00 a.m.

Conference Program Planning-San Francisco, 2001: Saturday, June 16, 9:30 a m.-12:30 p.m.

Conference Program Planning-Atlanta, 2002: Saturday, June 16, 9:30 a.m.-12:30 p.m.

Continuing Education: Sunday, June 17, 9:3011:00 a.m. 
Council: Friday, June 15, 8:00-10:00 p.m.; Monday, June 18, 8:00-10:00 p.m.

Discussion Group Chairs: Saturday, June 16, 11:30 a.m. $-12: 30$ p.m.

Forum for Science and Technology Library Research: Sunday, June 17, 2:00-4:00 p.m.

General Discussion Group: Sunday, June 17, 9:3011:00 a.m. Topic:

Government Information: Sunday, June 17, 8:3011:00 a.m.

Heads of Science Libraries Discussion Group: Sunday, June 17, 4:30-5:30 p.m.

Membership and Recruitment: Sunday, June 17 $11: 30$ a.m. $-12: 30$ p.m.

New Member Orientation: Saturday, June 16 , 8:00-9:00 a.m.

Nominating: Sunday, June 17, 8:30-11:00 a.m.

Oberly Award (closed): Saturday, June 16, 8:0011:00 a.m.

Organization and Planning: Saturday, June 16, 4:30-5:30 p.m.

Publications: Sunday, June 17, 11:30 a.m.-12:30 p.m.

Publisher-Vendor Relations Discussion Group: Saturday, June 16, 9:30-11:00 a.m.

Subject and Bibliographic Access: Saturday, June 16, 11:30 a.m.-12:30 p.m.

\section{University Libraries Section}

Program: Saturday, June 16, 2:00-4:00 p.m. Topic: "Outside/In: Seeing Ourselves as Others See Us"

Executive: Saturday, June 16, 8:30-11:00 a.m.; Monday, June 18, 8:30-11:00 a.m.

Campus Administration and Leadership Discussion Group: Saturday, June 16, 11:30 a.m.-12;30 p.m.

Communications: Saturday, June 16, 11:30 a.m.12:30 p.m.

Conference Program Planning-Atlanta, 2002: Saturday, June 16, 11:30 a.m.-12:30 p.m.; Monday, June 18, 11:30 a.m.-12:30 p.m.

Current Topics Planning: Sunday, June 17, 11:30 a.m.-12:30 p.m.

Organization and Bylaws: Sunday, June 17, 9:3011:00 a.m.; Sunday, June 17, 2:00-4:00 p.m.

Policy and Planning: Sunday, June 17, 9:30-11:00 a.m.

Public Service Directors of Large Research Libraries Discussion Group: Sunday, June 17, 2:00-4:00 p.m.

Standards and Guidelines Review: Saturday, June 16, 11:30 a.m.-12:30 p.m.; Sunday, June 17, 9:30-11:00 a.m

\section{Western European Studies Section}

Program: Monday, June 18, 9:00-10:30 a.m. Topic: "Exploding Spanish Canons: Including the Voices of Excluded Communities"

Executive: Saturday, June 16, 11:30 a.m.-12:30 p.m.; Sunday, June 17, 11:30 a.m.-12:30 p.m.; Tuesday, June 19, 9:30-11:00 a.m.

Cataloging Issues Discussion Group: Sunday, June 17, 11:30 a.m. -12:30 p.m.

Classical, Medieval, and Renaissance Discussion Group: Friday, June 15, 2:00-4:00 p.m.

College and Medium-Sized Libraries Discussion Group: Friday, June 15, 4:30-5:30 p.m.

Conference Program Planning-Atlanta, 2002: Saturday, June 16, 4:30-5:30 p.m.

General Membership: Monday, Jume 18, 10:30 a.m.-12:00 p.m.

Germanists Discussion Group: Sunday June 17, 9:00-11:00 a.m.

Membership: Saturday, June 16, 9:30-11:00 a.m.

Publications: Friday, June 15, 2:00-4:00 p.m.

Research and Planning: Saturday, June 16, 2:004:00 p.m.

Romance Languages Discussion Group: Sunday, June 17, 2:00-4:00 p.m

Scandinavian Discussion Group: Saturday, June 16, 11:30 a.m.-12:30 p.m.

Social Sciences and History Discussion Group: Saturday, June 16, 9:30-11:00 a.m.

Special Topics Discussion Group: Sunday, June 17. 11:30 a.m. $-12: 30$ p.m.

\section{Women's Studies Section}

Program: Monday, June 18, 9:00 a.m.-12:30 p.m. "Women Moving Mountains: Women and Organizations"

Executive: Sunday, June 17, 2:00-4:00 p.m.

All Committees: Sunday, June 17, 9:30 a.m.-12:30 p.m.

Awards: Friday, June 15, 2:00-5:30 p.m

General Membership Meeting: Sunday, June 17, 4:30-5:30 p.m.

Introduction to Women's Issues: Saturday, June 16, 11:30 a.m.-12:30 p.m. 
only people of color, but all library employees. APT members were provided with much of the documentation that SLRP gathered and analyzed. From there, they needed to do further research to see if this goal warranted one or more projects in the upcoming year. The staff environment APT consisted of five people, three librarians and two paraprofessional library staff members, who met two or three times a week for three months (March to May) to discuss and work on the following tasks:

- assessing assigned goal and objectives to determine the level of work currently being done by other team(s);

- seeking input from the library, both before projects are developed and throughout the process, and incorporating feedback as appropriate; and

- writing charge(s) and appointing project team(s) and notifying SLRP of charge and team members. ${ }^{2}$

\section{Recruitment and retention (R\&R) project team}

The 1999-2000 staff environment APT created two projects after reviewing the information and talking with the library and SLRP. One team was called staff fitness. This team examined the assessment of staff learning needs to prepare for future work. The other project team was $R \& R$. The criteria for appointing $R \& R$ team members were that they be individuals who possessed interpersonal skills; a commitment to minority recruitment and retention; program planning and organizational skills; and an interest in public relations and marketing. The team consisted of seven members representing the AfricanAmerican, Anglo, Hispanic, Middle Eastern, and Philippine cultures. They came from several library teams and included both academic librarians and classified staff.

\section{Charge and goals}

The staff environment APT created a specific charge that served as a guide for keeping the team on track. ${ }^{3}$ This charge, along with the purpose and goals, was also used when reporting to the library on the project team's progress.

The R\&R project team's goals were:

- encourage minority librarians to explore positions in academic libraries;
- recruit, retain, and promote minority applicants for positions in the library;

- overcome cultural and geographic barriers by providing a bridge to the retention of minority employees; and

- evaluate mentoring programs for all staff and librarians in relationship to the needs at the library.

To accomplish these goals, the staff environment APT created specific objectives for the R\&R project team to help guide its members and give them direction.

The objectives were to:

- develop a residency program that would attract library school minority graduates at the national level and/or develop an associates program that would attract potential minority library school students to the School of Information Resources and Library Science (SIRLS);

- create a blueprint for a mentoring program that would develop, retain, and promote staff and librarians; and

- work with the recruitment librarian to identify and develop mechanisms for increasing minority applicants in the UA Library pools."

\section{Project team development}

The APT handed the project off to the project implementation team (PIT) on August 13, 1999. The process of becoming a team begins with sessions in which members become acquainted with each other through exercises and personal statements that enable them to establish ground rules for working together effectively.

At the first meeting, we established a time and place for meeting and decided on a facilitator for our team-building session. After the team-building session, we met regularly every week for two hours.

\section{Mentoring}

Mentoring was one of the team's first objectives. Each team member reviewed the literature on mentoring and brought articles to the team for reading and discussion. The team members began a jigsaw discussion on mentoring, identifying major issues for further discussion. After reading the literature, the team discussed some of the important points and how mentoring would fit into our team-based environment. The investigation 


\section{As in many academic libraries all \\ over the country, attracting and \\ retaining people of color has \\ been a continuous, uphill battle.}

from the literature included: the definition of mentor/protégé, pros and cons, and organizational and cultural values and support. The major concern the team had to keep in mind was that the mentoring program was for everyone, not just librarians. Library staff members on the project team were able to make sure the team addressed issues and concerns that were important to everyone.

The project team also met with another library member who had started a small mentoring program for her team. She was able to advise the team of some of the accomplishments and challenges in developing a mentoring program.

\section{Recruitment}

The team gathered information through needs assessment with focus groups, discussed the possibility of surveying former employees, and listened to a presentation from the current assistant to the dean for recruitment and retention to learn about the processes and develop recommendations. The team worked with him to increase minority librarians in the candidate pool by creating a recruitment marketing brochure, sending out recruitment letters, and revising the affirmative action and diversity guidelines when meeting with the search committees.

The team divided into two subgroups, one to continue work on mentoring and another to investigate resident and associates programs. The authors were both part of the subgroup to research resident and associates programs. This subgroup worked on the completion of a literature review on associates/residency programs and shared information with the project team via a jigsaw exercise. The subgroup also interviewed a new minority librarian regarding his internship program and residency program at SUNYBuffalo University.

Another approach to the process was for the two authors to travel to Florida (paid for from money in the budget allocated to the project) to meet with Spectrum ${ }^{5}$ students at the Florida State Library Association conference at the University of South Florida. The goal was to encourage students to consider careers in academic librarianship.

After conversations with the dean and team leaders, it was clear that a residency program had more support at this point. SIRLS was fighting for accreditation, making the associates option less viable.

The subgroup on residency/associates program then developed a guide (see R\&R web page) to filling out the team proposal template, a generic position description, expectations, milestones, and feedback questions and answers. The purpose of this guide was to fully support the residents by including expectations and setting milestones that included specific information on how teams planned to address the following:

- full scope of professional work;

- experience with faculty/partnerships/instruction;

- experience with library faculty assembly;

- assistance in preparing for presenting a paper/poster session/panel discussion;

- assistance with meeting team requirements;

- building interpersonal skills;

- how to set learning, scholarship, and performance goals working with the team leader and the program coordinator;

- understanding a team-based learning organization; and

- participating in cross-functional teams.

\section{Outcomes}

- The R\&R project was handed off to the Staff Organizational Systems (SOS) on September 7 .

- The R\&R project team made all of its progress, mentoring information, and handouts available on the R\&R Web site. ${ }^{6}$

- A program coordinator, Pat Tarin, was hired in the summer of 2000 to coordinate implementation of the residents program.

\section{Next steps}

Tarin was introduced to the final report from the R\&R team. She has held focus groups with team leaders, minority librarians, and the library's Junior Librarians Round Table to 
receive feedback on how the residents program could be implemented. The goal is that residents will have a positive experience and that the review process will provide us with information on whether to continue the program or to replace it with an associates program.

Tarin has followed the R\&R project recommendations and fleshed them out to introduce program implementation with detailed direction and information that will include the processes for:

- internal proposals and review of applications;

- elements of mentoring;

- framework established;

- performance measures and expectations; and

- recommendations on services related to collections, relationships, etc.

The program coordinator developed a brochure specific for the $\mathrm{SABIO}^{7}$ Residents Program and a Web page. A comprehensive plan also has been developed for the distribution of the brochures beginning at ALA Midwinter on January 2001 and the ALIS conference.

There are expectations of full support from the dean of libraries that will create an environment of trust among teams who apply and contribute to the program. Internal proposals will be required to express the interest and clearly explain their plans for the professional development of the resident. Applications for SABIO residents will be considered at the end of the spring semester 2001, and we hope to have hired the two SABIO residents by the fall.

\section{Conclusion}

A minority resident program benefits both the library and the profession through:

- actively and aggressively recruiting minority professionals into academic librarianship;

- obtaining new and fresh perspectives (recent graduates) to help with strategic planning within the library;

- adding diverse viewpoints within the library and the team environment;

- rewarding librarians and library staff members for contributing to the development of leadership for the profession; and

- giving librarians and library staff an opportunity to formalize mentoring skills.
The resident benefits through:

- gaining work experience in an academic library setting;

- getting exposure to a team-based learning organization;

- exploring critical issues facing academic libraries through strategic work;

- participating in national conferences and workshops;

- collaborating with junior and senior librarians in a formal or informal mentoring setting;

- increasing interpersonal skills by interacting with librarians and library staff;

- defining future career goals without the added pressure of working toward continuing status;

- authoring or coauthoring one article in a peer-reviewed or national journal; and

- receiving mentoring from experienced librarians.

These benefits will be achieved by following the program's measures and expectations.

Overall, it has been an extraordinary learning experience to be involved in the planning stages and to produce the blueprint for implementing the SABIO Residents Program at the University of Arizona.

\section{Notes}

1. Strategic Long-Range Planning Team, "About SLRP and Its Current Team Roster," January 2001. Available online at http://dizzy. library.arizona.edu/library/teams/slrp/team. html (21 January 2001).

2.- "Charge to 2000/2001 Action Plan Teams," January 2001. Available online at: http://dizzy.library.arizona.edu/library/ teams/slrp/chargetoAPTs.html (21 January 2001).

3. Recruitment and Retention Project Team, "Recruitment and Retention Project Team Charge," March 2000. Available online at: http://dizzy.library.arizona.edu/library/ teams/recruit/charge.html (21 January 2001).

4. Ibid.

5. Spectrum is an ALA scholarship program for minorities.

6. "Recruitment and Retention Project Team Charge."

7. SABIO is Spanish for "a wise one, a sage, a scholar." 